\title{
THE INFLUENCE OF THE AIR TEMPERATURE AND THE MASS RATIO OF ZEOLITE AND INERT MATERIAL ON THE EFFICIENCY OF THE FLUIDIZED BED DRYING PROCESS - EXPERIMENTAL RESEARCH
}

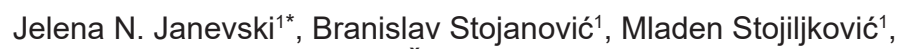
Aleksandar Dedić ${ }^{2}$, Predrag Živković ${ }^{1}$

(ORIGINAL SCIENTIFIC PAPER) UDC 66.096.5:549.67

${ }^{1}$ Faculty of Mechanical Engineering, University of Niš, Niš, Serbia

2 Faculty of Forestry, University of Belgrade, Belgrade, Serbia

Fluidization has become a subject of wide interest in chemical engineering during the past few decades. This paper presents one part of the results of the kinetics research into the drying of fine grained material in a two-component fluidized bed. A review of theoretical and experimental investigations of aerodynamics of the fluidized bed and minimum fluidization velocity of particles are given, with a special insight into two-component fluidized beds (binary mixture), as well as the basics of heat and material transfer through a fluidized bed. The interaction between complex hydrodynamics and transfer mechanisms complicates the analysis, design and prediction of gas-fluidized-bed processes. Based on experimental investigations, where zeolits was used as a representative of fine grained material, and polyethylene as a representative of the inert material (another component), an analysis of the influence of working parameters on drying in a two-component fluidized bed has been performed. Before that, the minimum velocities for two-component fluidized bed with particles of different sizes and densities were studied experimentally. Also, the ability of elutriation of fine particles from the fluidized bed is described.The present paper deals with the experimental results on the influence of the considered parameters, such as the drying agent temperature and the mass ratio of zeolite and the inert material on the drying curve. The participation of the inert material can considerably increase the intensity of heat and material transfer in the fluidized bed.
Keywords: fluidization, bed, experiment, particle, zeolite, drying

\section{Introduction}

Any mass of particles, whether they are solid, liquid or gas, which is suspended in a continuous fluid because of the motion of the fluid between the particles, represents and can be classified as a fluidized system. Quantitative understanding of the hydrodynamics of fluidization is needed for the design and scale-up of efficient new reactors in the petroleum, chemical and electric power industries. In gas-solids fluidization, fluidized beds have been used more frequently in drying operations than in any other single application [1]. This fact has been crucial to fluidization finding wide application in many industrial processes such as drying of fine-grained material, transportation of powdered materials, coal combustion [2], freezing of food products, etc. The fundamental importance of the phenomenon of fluidization to the majority of chemical engineering operations and processes and hence to phase-change separations in which two phases must be brought into contact is recognized. Many operations in a fluidized bed are characterized by the processes of heat exchange between the gas and solid particles which include the mass transfer [3]. One of these processes is the material drying in a fluidized bed. Fluidized beds are frequently selected as the processing equipment because of their excellent heat transfer properties and the ease in controlling the transfer of solids into, out of, and within the process system [4]. The drying rate in the fluidized bed is much higher than that in conventional hot air drying because the heat and mass transfer on the material surface is much higher. The first commercial fluidized bed dryer was installed in the USA in 1948 to dry dolomite or blast furnace slag [5]. Since then, hundreds of fluidized bed dryers have operated worldwide, primarily for granular materials that can be easily fluidized, such as sand, grains, chemical crystals and fertilizers.

The main goal of the functional food and nutraceutical industries is to provide products that contain biologically active (bioactive) compounds that offer health benefits for the management or prevention of chronic and/or degenerative disease. Drying is just one of the stages that may be included in functional food and the nutraceutical product development. The process of drying granular material in a fluidized bed with an infill or the so-called inert material has been of particular interest to many researchers [6], [7], [8]. An inert medium fluidized bed dryer can be defined as a fluidized bed of fine and coarse particles for fine-grained

*Author address: Jelena Janevski, University of Niš, Faculty of Mechanical Engineering,

Aleksandra Medvedeva 14, Niš, Serbia

E-mail: jelena.janevski@masfak.ni.ac.rs

The manuscript received: November, 16, 2018.

Paper accepted: December, 01, 2018. 
material drying whereby the coarse particles serve as the inert material for heat transfer media.

\section{Fundamentals of Fluidization}

To understand and visualize clearly the expansion and fluidization behaviors of the particles at ambient conditions Geldart [9] made a very useful classification. He classified the particles into four groups $A, B, C$ and $D$ (Figure 1.).

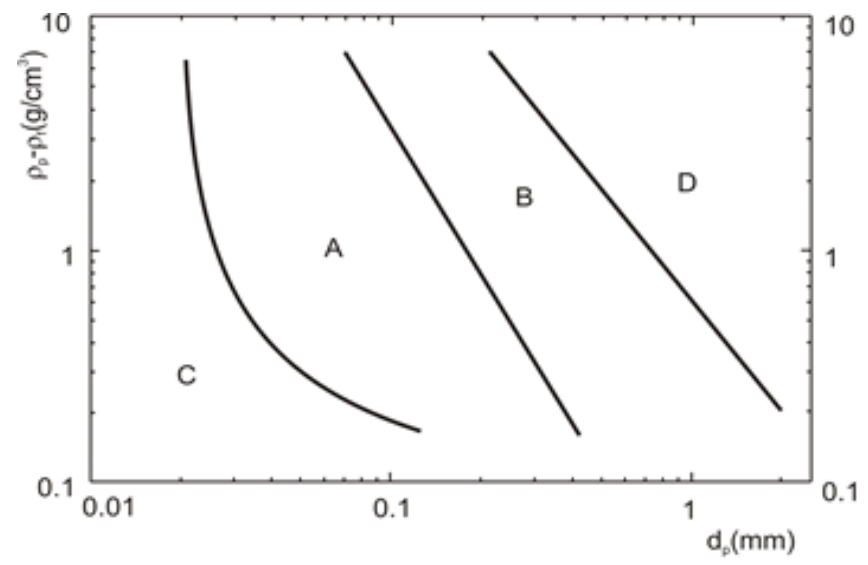

Figure 1. Geldart's classification of particles

Group A: For this group, the characteristic value varies between 30-100 $\mu \mathrm{m}$ in most cases. They are fine and aeratable particles, hence they fluidize nicely. When the gas flow is cut off, the bed collapses slowly.

Group B: Sand particles are good examples for this group. They cannot be fluidized as homogenously as Group A particles and they start to bubble when $U_{m f}$ is reached. A bed of Group B collapses quickly when the gas flow is cut off.

Group C: They are finer than Group A particles with typical dp values less than $20 \mu \mathrm{m}$ and density differences are larger than $1 \mathrm{~g} / \mathrm{cm}^{3}$. These particles are typical of flour.

Group D: They are the coarsest particles which can be fluidized poorly. They can be spouted preferably and yield a better mixing quality when compared with fluidization. For most cases, $d_{p}$ is greater than $1 \mathrm{~mm}$.

Ability of elutriation of fine particles

In the elutriation of one particle species from a gassolid fluidized bed a very interesting phenomenon is found, namely the ratio of the elutriation rate to the particle concentration gradually decreases as the particle concentration in the fluidized bed becomes larger [10].

When particles of a wide size distribution are fluidized, fine particles are carried over from the fluidized bed with the gas stream when the gas velocity exceeds the terminal velocities of the particles. Many works have been carried out on the elutritation rate from a fluidized bed, and many empirical equations have been proposed to estimate the elutriation rate constant. The conclusions are:

- In the case of fine particles belonging to group A of
Geldart classification, the elutriation rate constant was not affected by the diameter of the bed. For coarse particles, the rate constant is strongly affected by the diameter and the rate constant increased with a decrease in the diameter.

- When coarse particles from group B of Geldart classification were fluidized, the elutriation rate constant decreased with an increase in the minimum fluidizing gas velocity at constant gas velocity. For fine particles, the constant rate was not affected by the minimum fluidizing velocity.

Multi-component fluidization is widely used in chemical engineering in connection with separation processes and low-temperature combustion of coal and other dispersed fuels and also with various technologies of thermochemical processing of powdered materials in fluidized beds of inert particles such as drying, burning, oxidation and others.

In the multi-component fluidized bed, the elutriation rate constant $K^{*}$ is defined by equation [1]:

$d W X_{f i} / d \tau=-K_{i}^{*} \cdot A_{t} \cdot X_{f i}$

where:

$K^{*}(\mathrm{~kg} / \mathrm{m} 2 \mathrm{~s}) \quad$ elutriation rate constant

$A_{t}(\mathrm{~m} 2) \quad$ cross-sectional area of fluidized bed

$W(\mathrm{~kg}) \quad$ weight of fluidized bed

$X_{f i}(-) \quad$ mass fraction of particle

$K^{*}$ has been regarded until now as being constant regardless of the mass fraction of particles in a fluidized bed.

Minimum fluidization velocity of a binary (two-component) mixture

In the case of two-component mixture fluidization, the transition to fluidized condition occurs gradually because finer particles pass into a fluidized state at lower fluid velocities. Heavier particles transit more slowly to the fluidization state. When a small amount of fine powder is added to coarser one, the minimum fluidisation velocity of the mixture is often much less than that of the coarser alone.

The minimum fluidization velocity of a fluidized bed with a single component bed material - a bed material with particles of relatively narrow particle size distribution and of similar particle density is well defined. For mixtures of particles of different sizes or densities (Table 1), especially for the highly segregating systems, the definition and determination of the minimum fluidization velocity are not as straightforward.

Mixing characteristic of binary (two-component) mixture in a gas-solid fluidized bed

Generally, the gas fluidized beds have excellent mixing characteristics for non-segregating particle systems. In industrial solids mixing it is often required to mix particles which widely differ in physical properties: size, den- 
sity and/or shape. A qualitative model for particle mixing in a gas fluidized bed has been developed by Rowe [11] based on four physical mechanisms: the overall particle circulation, the interchange between the wake and the bulk phases, axial dispersion and segregation.

Table 1. The minimum fluidization velocity of binary mixtures

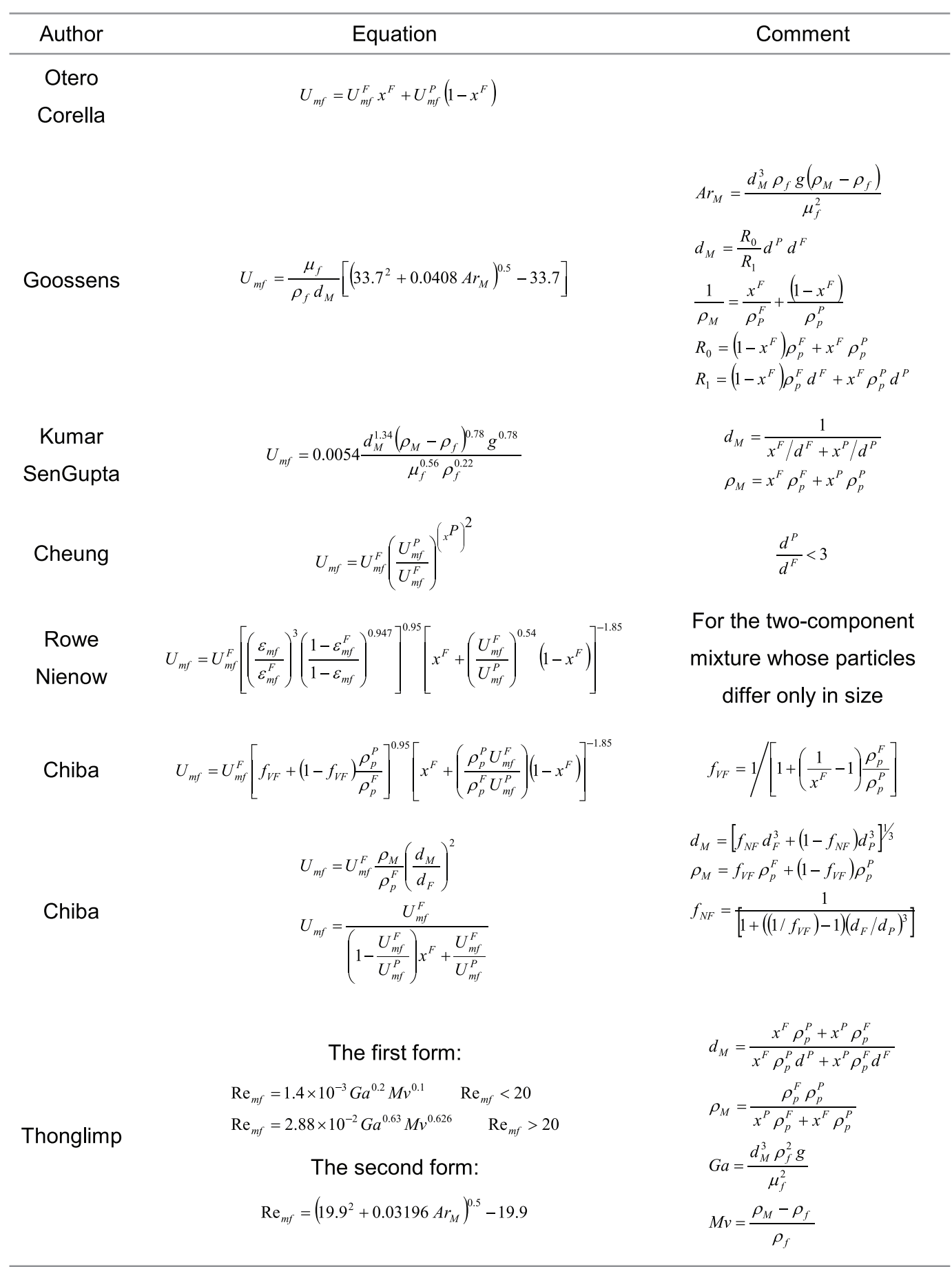

Segregation of particles can occur in fluidized beds of binary (two-component) mixtures. Segregation is a function of the difference in density and the particle size of the components, as well as the gas velocity in the bed [12]. Components with different densities and the same particle size will be separated considerably from the components of different particle sizes and similar densities [13]. Wu and Baeyens [14] gave an equation for calculating the logarithmic fitting mixing index which provides a surplus of gas flow necessary to prevent segregation in a fluidized bed with a wide range of particle size distribution:

$M=1-0.0067 d_{R} 1.33\left(\frac{G_{B}}{A}\right)^{-0.75}$ 
where:

$$
\begin{array}{ll}
\left(\frac{G_{B}}{A}\right)(\mathrm{m} / \mathrm{s}) & \text { visible bubble flow rate } \\
d_{R}(-) & \text { particle diameter ratio } \\
M(-) & \text { mixing index }
\end{array}
$$

Sahoo and Roy [15] have analyzed the characteristics of mixing the two-component fluidized bed with particles from groups B and D according to Geldart's classification. The experimental values of the mixing index were calculated using the following expression:

$$
I_{M}=\frac{X^{*}}{\bar{X}_{b e d}}
$$

$$
\begin{array}{ll}
I_{M}(-) & \text { the mixing index } \\
X^{*} & \text { the percentage of jetsam particle in any layer } \\
\bar{X}_{\text {bed }} & \text { the percentage of jetsam particle in the bed }
\end{array}
$$

In the fluidization of the particles, the authors pulled the samples of the material from the column on the sidemounted port, which could be located at every $2 \mathrm{~cm}$ height, from either side of the bed. For the fluidized bed, in their conditions, the mixing index was shown as:

$$
I_{M}=0.3725\left(\frac{\bar{d}_{P}}{d_{F}}\right)^{0.3679}\left(\frac{h_{B}}{D_{C}}\right)^{-0.4864}\left(\frac{H_{S}}{D_{C}}\right)^{0.8258}\left(\frac{U}{U-U_{F}}\right)^{0.5084}
$$

where:

$$
\begin{array}{ll}
d_{p}(\mathrm{~m}) & \text { the average particle size of the mixture } \\
d_{F}(\mathrm{~m}) & \text { the diameter of the flotsam particle } \\
D_{C}(\mathrm{~m}) & \text { the diameter of the column } \\
h_{B}(\mathrm{~m}) & \text { the height of particles layer in the bed }
\end{array}
$$$$
\text { from the distributor }
$$$$
H_{s}(\mathrm{~m}) \quad \text { the initial static bed height }
$$$$
U(\mathrm{~m} / \mathrm{s}) \quad \text { superficial velocity of the fluidizing medium }
$$$$
U_{F}(\mathrm{~m} / \mathrm{s}) \quad \text { minimum fluidization velocity of the flotsam }
$$$$
\text { particles }
$$

In their presented research, the dispersion of particles was analyzed both in the horizontal and the vertical direction by the gas of the fluidized bed. By solving the differential equation with which, with some simplifications, they described their own model of mixing in a fluidized bed, the authors expressed the concentration of precipitating particles as:

$C_{j}=\int e^{-\int\left(\frac{F \times U}{F \times D_{S V}+D_{S H}}\right) d Z} d Z$

where $Z$ is the height of any particle bed, measured from the distributor.

The mixing index can be calculated based on the previously given concentration, using the following expression:

$$
I_{M}=C_{j}\left(\frac{W}{J}\right)
$$

where:

$W(\mathrm{~kg})$

$J(\mathrm{~kg})$

in the bed

From their research, it is evident that theoretically more values of the mixing index in the bed which is at the initial fluidization are closer to the static conditions of the bed than in the developed fluidization in which the transfer of particles from the bed is more intense.

\section{Drying in a fluidized bed}

Drying of materials on inert solid carriers is a commercial technology to produce dry powders. Although this technique was developed in the 1950s, over the past four decades drying on inert particles has found interest mainly because of its ability to produce powders even from the coarsely dispersed liquid feed at evaporation rates competitive to spray, drum and film-rotary dryers.

The analysis of the drying phenomenon in fluidized beds is more complicated than that of the heat or mass transfer alone. The drying agent flows around the material particles there by intensifying the exchange of heat and mass transfer between the drying agent and the solid particles. It is considered that the distribution of temperature and the moisture content of particulate materials is practically uniform in the fluidized bed.

Dryers are essentially vertical with drying proceeding during vertical transportation of wet materials. Jariwara and Hoelscher [16] reported that fine sand mixed with the same mass of starch can improve the flow characteristics of starch. Chancellor [17] suggested that a mixture of grains and sand can reduce a localized overheating of grain. Sand would act as the inert material since it can absorb heat from a heated plate, and transport it uniformly through a bed of sand and grains.

Lee and Kim [18] reported that fine powders can be successfully dried in an inert medium fluidized bed where fine powders are dried in a fluidized bed of coarse particles. The agglomerates of fine powders are disintegrated by collisions to coarse particles so that fine powders are uniformly dispersed in the bed. Drying experiments with starch were carried out in a $0.083 \times 0.8$ $\mathrm{m}$-high stainless steel column. A mixture of coarse glass beads $\left(d_{p}=0.4 ; 1 \mathrm{~mm}\right)$ and wet starch $\left(d_{p}=16.3 \mu \mathrm{m}\right)$ was supported on a perforated plate. The minimum fluidized air velocities were determined as 0.13 and $0.54 \mathrm{~m} / \mathrm{s}$, respectively. The dried solid particles entrained from the bed were collected in a bag filter. The individual phase hold-ups in an inert medium fluidized bed were calculated from the following relationship:

$\frac{\Delta P}{\Delta L}=\left(\varepsilon_{g} \rho_{g}+\varepsilon_{l} \rho_{l}+\varepsilon_{s f} \rho_{s f}+\varepsilon_{s c} \rho_{s c}\right) g$ 
$\varepsilon_{\mathrm{g}} \rho_{\mathrm{g}}+\varepsilon_{1} \rho_{1}+\varepsilon_{\mathrm{sf}} \rho_{\mathrm{sf}}+\varepsilon_{\mathrm{sc}} \rho_{\mathrm{sc}}=1$

where:

$\varepsilon_{g}(-)$

$\varepsilon_{\text {, }}(-)$

$\varepsilon_{s c}(-)$

$\varepsilon_{s f}(-)$

$\rho_{g}\left(\mathrm{~kg} / \mathrm{m}^{3}\right)$

$\rho_{\text {, }}\left(\mathrm{kg} / \mathrm{m}^{3}\right)$

$\rho_{s c}\left(\mathrm{~kg} / \mathrm{m}^{3}\right)$

$\rho_{s f}\left(\mathrm{~kg} / \mathrm{m}^{3}\right)$

gas phase hold-up

liquid phase hold-up

phase hold-up of inert particles

phase hold-up of fine particles

air density

water density

inert particles density

fine particles density

$\frac{\Delta P}{\Delta L}\left(\mathrm{~kg} / \mathrm{m}^{2} \mathrm{~s}^{2}\right)$ pressure drop over the length of the bed

\section{Experimental}

\section{Zeolites}

Zeolites are a large group of natural and synthetic hydrated aluminum silicates. The atomic structures of zeolites are based on three-dimensional frameworks of silica and alumina tetrahedra. There are about fortyfive natural zeolites. They form in a number of relatively low temperature geologic environments. Although some natural zeolites occur in large amounts, they offer only a limited range of atomic structures and properties. Synthetic zeolites have a wider range of properties and larger cavities than their natural counterparts. They were first produced in the 1950s. Today more than 100 different zeolites have been made, and the annual production of synthetic zeolites exceeds 12000 tons. Zeolites are manufactured in a number of ways; one important technique involves mixing of sodium, aluminum, and silica chemicals with steam to create a gel (an amorphous, noncrystalline, water-rich solid).

Zeolites are hydrated alumina silicates in a crystalline form. The framework of zeolites consists of three dimensional networks of $\mathrm{SiO}_{4}$ and $\mathrm{AlO}_{4}$ tetrahedrals linked to each other via sharing oxygen atoms. This structure forms channels and consistent voids occupied by water molecules and cations to balance the charge of the whole framework. Due to the mobility of the cations, zeolites have a high ion-exchange capacity. They are commonly used as commercial adsorbents and often named as the mineral of 21 st century.

\section{Apparatus}

The own arrangement of the fluidization apparatus is shown in Figure 2. The techniques applied for fluidizing the bed are manufactured to suit specific requirements of this experimental research, and a description of the apparatus is given below. The apparatus consists of the following components: variable speed fan (4), sections for air flow measuring with a metering station, electric heating (2), fluidized bed (1), the device for measurement, regulation and registration process $(3,5)$. A fluidization bed has a circular cross-section with the inner diameter of 120 $\mathrm{mm}$ and the height of $600 \mathrm{~mm}$. It was made of plexiglass, which allowed the visual monitoring of the process.

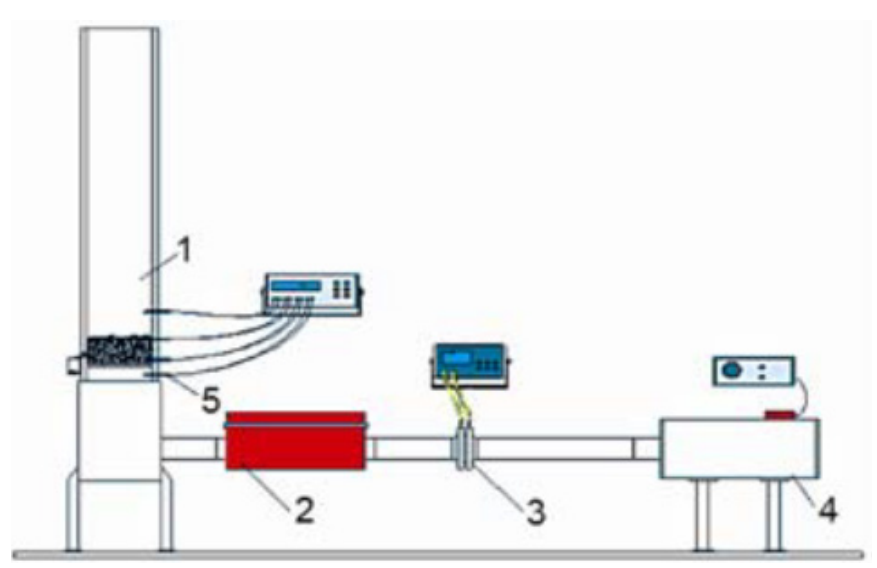

Figure 2. Schematic layout of the apparatus

At the bottom of the column there is a distributor for air with 2800 holes with a diameter of $0.9 \mathrm{~mm}$ evenly distributed over the whole surface. Under the distributor, a canvas prevents the degradation of the material and provides an even distribution of air in the cross-section of the column. The openings for thermocouples setting are located at the same height as the fluidized bed. An opening for the sampling of the material to be dried is positioned on the side. Immediately above the distributor, there is an opening for discharging the apparatus. The measurement of the air flow was performed using a standard metering station that was previously calibrated and installed in a pipe line with a diameter of $50 \mathrm{~mm}$. The pressure drop was registered by a micromanometer. An electrical heater was used for air heating.

The measurement of the temperature was performed with a chromel-alumel thermocouple $(0.2 \mathrm{~mm}$ in diameter). The inlet air temperature was measured directly under the distribution plate; the temperature of the fluidized bed was measured at half the height of the bed. All thermocouples were connected to a data acquisition system. The regulation of all operating parameters was performed manually. Before the examination of the drying kinetics of the material in the fluidized bed, a specific mass of the inert material was poured into the fluidization column, followed by the adjustment of the working parameters of the drying process: the inlet air flow and temperature. After heating the inert material and the column, i. e. reaching the stagnant state, the examination process began and a measured mass of the wet material was introduced into the bed. At pre-determined time intervals, which depended on the period of drying, samples of the dried material were taken from the bed through an opening on the column wall, and after their mass was determined, they were placed in the electric chamber dryer for further drying. The mass of the dry material of each sample was determined, i.e. the absolute humidity of each sample was calculated. The fluidization air flow was set manually for each experiment. Series of 29 experiments were conducted. 


\section{Results and discussion}

In these experiments, zeolite was sifted through standard sieves and divided into fractions, the middle particle diameters of which were: $0.3 \mathrm{~mm}, 0.5 \mathrm{~mm}, 0.7$ $\mathrm{mm}$, and $0.9 \mathrm{~mm}$. Each fraction of zeolite was determined by the following characteristics: the average particle diameter, actual density, bulk density, porosity of the bed at minimum fluidization and minimum fluidization velocity $\left(d_{p}, \rho_{p}, \rho_{n}, \varepsilon_{m f}, U_{m f}\right)$.

The inert material was polyethylene (PE) in the form of a cylinder with an oval base of $a=3.8 \mathrm{~mm}, \mathrm{~b}=4.4$ $\mathrm{mm}$, and $\mathrm{h}=4.0 \mathrm{~mm}$ in dimensions. The real and bulk density of zeolite and PE were determined experimentally; the values of the specific heat capacity and thermal conductivity of the material were taken from the reference literature (Table 2.). As the particles of zeolite of all fractions were monodisperse, the equivalent diameter of the particle was determined on the basis of the screen size, and the equivalent diameter $(\mathrm{m})$ of the particles of the inert material PE was calculated by the expression:

Table 2. Characteristics of zeolite and polyethylene

\begin{tabular}{|c|c|c|c|c|c|c|c|}
\hline Diameter & Density & $\begin{array}{l}\text { Bulk } \\
\text { density }\end{array}$ & $\begin{array}{l}\text { Porousity } \\
\text { at } U_{m f}\end{array}$ & $\begin{array}{l}\text { Spec. } \\
\text { thermal } \\
\text { capacity }\end{array}$ & $\begin{array}{l}\text { Thermal } \\
\text { conductivity }\end{array}$ & \multicolumn{2}{|c|}{$\begin{array}{l}\text { Min. fluidiz. velocity } \\
U_{m f}(\mathrm{~m} / \mathrm{s})\end{array}$} \\
\hline$d_{p}(m m)$ & $\begin{array}{l}\rho_{\mathrm{p}} \\
(\mathrm{kg} / \mathrm{m} 3)\end{array}$ & $\begin{array}{l}\rho_{n} \\
(\mathrm{~kg} / \mathrm{m} 3)\end{array}$ & $\varepsilon_{\mathrm{mf}}(-)$ & $\mathrm{C}_{\mathrm{p}}(\mathrm{kJ} / \mathrm{kgK})$ & $\lambda_{\mathrm{p}}(\mathrm{W} / \mathrm{mK})$ & exper. & calcul. \\
\hline \multicolumn{8}{|c|}{ Zeolite } \\
\hline 0.3 & 1770 & 740 & 0.59 & & & 0.04 & 0.046 \\
\hline 0.5 & 1765 & 781 & 0.57 & & & 0.11 & 0.12 \\
\hline 0.7 & 1815 & 782 & 0.58 & & & 0.19 & 0.21 \\
\hline 0.9 & 1870 & 780 & 0.58 & & & 0.27 & 0.30 \\
\hline \multicolumn{8}{|c|}{ Polyethylene } \\
\hline 4.06 & 905 & 580 & 0.37 & 2.51 & 0.32 & 0.85 & 0.833 \\
\hline
\end{tabular}

Table 3. Minimum fluidization velocity

\begin{tabular}{lll}
\hline Z/l (-) & \multicolumn{2}{l}{ Minimum fluidization velocity $\cup_{\mathrm{mf}}(\mathrm{m} / \mathrm{s})$} \\
& experimental & calculating \\
\hline $90 / 10$ & 0.17 & 0.16 \\
$80 / 20$ & 0.22 & 0.20 \\
$70 / 30$ & 0.28 & 0.24 \\
$60 / 40$ & 0.34 & 0.30 \\
$50 / 50$ & 0.42 & 0.37 \\
$40 / 60$ & 0.48 & 0.45 \\
$30 / 70$ & 0.58 & 0.55 \\
$20 / 80$ & 0.71 & 0.67 \\
$10 / 90$ & 0.84 & 0.82 \\
\hline
\end{tabular}

The minimum fluidization velocity of all fractions of zeolite and PE was determined experimentally (Figure 3.), on the basis of standard measurements, depending on the pressure drop in the bed of the fluidization velocity.

An expression by Goossens [19] was used for the calculation of the minimum fluidization velocity of the mixture, and it showed the best agreement with the experimental data.

The comparative results of calculation and experimental determination of the minimum fluidization velocity of the mixture of zeolite and PE are given in Table 2 and Table 3. The characteristics of the materials used for the experimental research are presented in the same Tables. The experimental research of the drying kinetics of finegrained material in a fluidized bed included the variation of certain operating parameters with the greatest influ- ence on the process as follows: the particle size of finegrained material (zeolite), fluidization velocity, air temperature, and the drying ratio of the mass fractions of zeolites and the inert material.

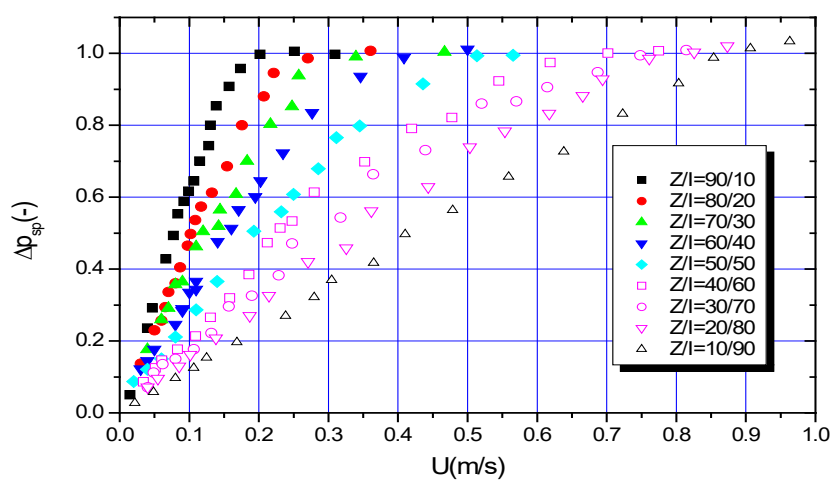

Figure 3. Minimum fluidization velocity (experimental) of the mixture of zeolite $\left(d_{p}=0.5 \mathrm{~mm}\right)$ and $P E$

The influence of the air temperature

It is known that with the increase of the air temperature, the drying intensity increases. This can also be seen in the case of drying of fine-grained material in a fluidized bed with the inert material as shown in Figure 4. The time required for drying the material to the condition at a higher operating temperature of the drying process is significantly reduced. It should be kept in mind that in this case the heat and material exchange mechanisms, 
and the presence of the inert material in the layer also positively influences the intensification of the process. It is noted from the picture that the increase in the temperature of the drying agent from $41^{\circ} \mathrm{C}$ to $55^{\circ} \mathrm{C}$ has the same effect on the drying intensity as the introduction of the inert component into the layer.

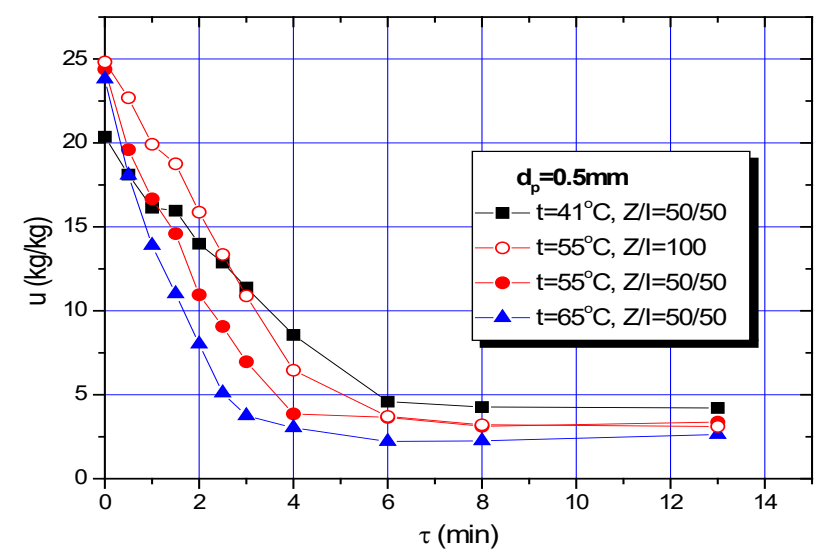

Figure 4. Drying curves of mixtures of zeolite $d_{p}=0.5 \mathrm{~mm}$ and polyethylene in a fluidized bed for different temperatures

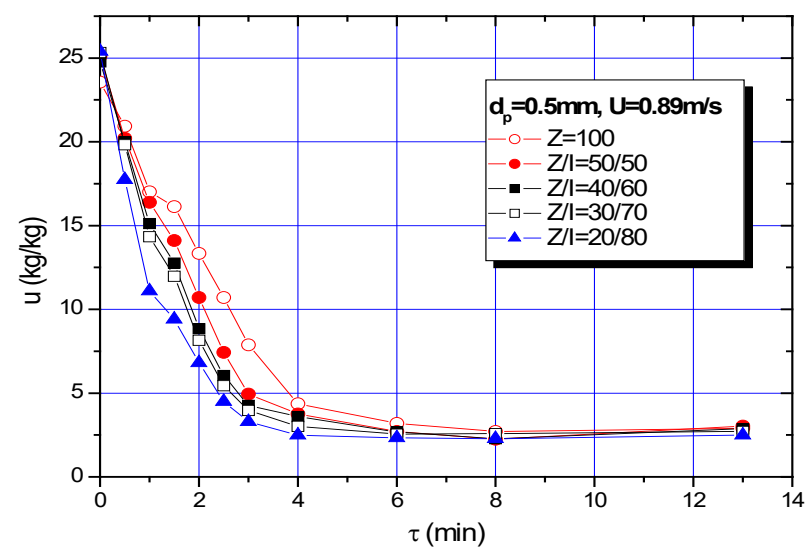

Figure 5. Drying curves of zeolite mixtures $d_{p}=0.5 \mathrm{~mm}$ and polyethylene for different mass ratio of zeolite and polyethylene

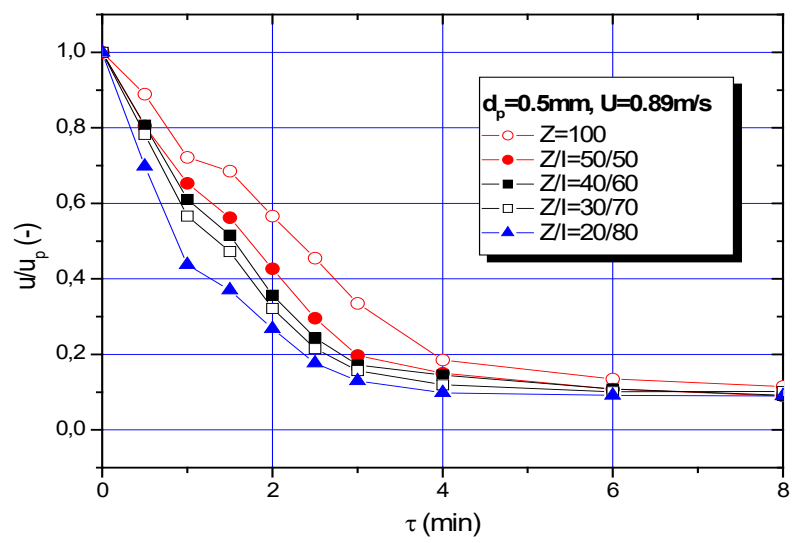

Figure 6. Normalized drying curves for particles $d_{p}=0.5 \mathrm{~mm}$ The influence of the mass ratio of zeolite and inert material $(\mathrm{Z} / \mathrm{I})$
The influence of the mixing ratio of zeolite and inert material on the kinetics of drying was certainly of utmost importance for the experimental analysis. In order to obtain valid and high-quality conclusions which could be applied to a wider range of fine-grained materials, a series of experiments with a different proportion of the inert material (polyethylene) in the fine-grained material (zeolite) was carried out. For each of these experiments, the weight of the zeolite was constant, and the mass of polyethylene was adapted to the given percentage contribution. Figure 5 shows the obtained measurement results for the selected zeolite fraction $d_{p}=0.5 \mathrm{~mm}$ and different mass ratio of zeolite and polyethylene.

Analyzing the experimentally obtained dependences shown in Figure 5, it is noted that the drying time at the ratio of zeolite and inert material $20 / 80$ is the shortest. As the participation of zeolite increased and the participation of polyethylene decreased, the time required to remove moisture from the fine-grained material increased. The obtained results are a direct consequence of the heat exchange between zeolite and inert material, whereby the influence of the inert material on the aerodynamics of the fluidized bed must always be taken into account. During the experimental investigation of the process of drying in a fluidized bed with a lower amount of zeolite compared to the amount of polyethylene, more intense mixing of particles is observed - and therefore their more frequent mutual contact. With that, the process of exchanging heat and matter has been intensified, which directly influenced the reduction of the time required for the zeolite drying.

Considering the fact that the initial moisture of the fine-grain material-zeolite in the analyzed experiments did not have the same value, in order to compare the obtained drying curves better it is necessary to normalize them, that is, all the values obtained during one experiment should be divided with the initial value of the moisture of the material. The dependence of normalized values of absolute moisture on time is shown in Figure 6 from which the influence of the inert material in the drying process can be seen more clearly.

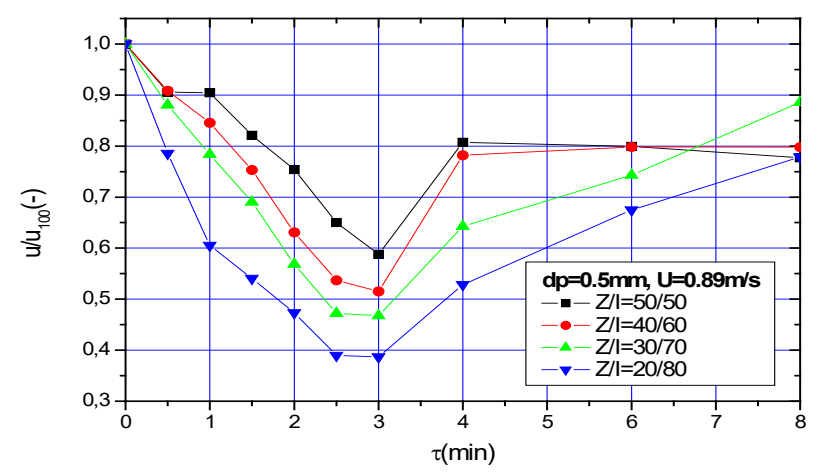

Figure 7. Normalized drying curves for particles $d_{p}=0.5 \mathrm{~mm}$

The obtained normalized moisture values of the finegrained material in a layer with the inert material can be 
divided by the moisture obtained for drying the pure zeolite at the same time. Thus, the drying rate at different $Z / /$ relationships is obtained (Figure 7).

\section{Conclusions}

Based on the obtained results and the conducted analysis, the following conclusions can be made

- The primary motive of the conducted experimental research was to determine the influence of the inert material on the kinetics of drying.

- The results of the experiments clearly indicate that the inert material in the fluidized bed accelerates the drying process and exhibits positive effects on the intensification of the process; in all cases of percentage zeolite ratios, the drying time is reduced.

- It is important to find an adequate expression for determining the minimum fluidization velocity of this mixture based on the relevant literature, with a satisfactory agreement with experimental values.

- Experimental studies have shown that, due to the possible segregation of larger particles, it is very important to reconcile the ratio of the size of bulk particles with their density. With the increase in the particle size, lower density materials should be used.

- $\quad$ Experimental research confirmed the expected fact that with the increase in the temperature of the air, the intensity of drying in the fluidized bed increases.

- This is also evident in the case of zeolite drying in a bed with the inert material $(Z / I=50 / 50)$, where the time required for the material drying at higher operating temperatures is considerably reduced.

- It is evident that the mixing ratio of zeolite and the inert material is important for the drying process. Based on the experimental results, it has been concluded that at the ratio of zeolite and inert material 20/80, the drying time is the shortest. This means that higher drying rates are achieved with larger amounts of the inert material in the bed.

\section{References}

[1] D. Geldart, Gas Fluidization Technology, John Wiley, U. K. 9 (1986), 9, 33-54, 17.

[2] S. N. Oka, Fluidized bed combustion, Marcell Dekker, New York, Basel, 2004

[3] J. N. Janevski, B. Stojanovic, M. Stojiljkovic, M. Vukic, Experimental research of the influence of particle size and fluidization velocity on zeolite drying in a two-component fluidized bed, Thermal Science, 20 (1) (2016) 103-111

[4] W. K. Ng, R. B. H. Tan, Investigation of drying Geldart $\mathrm{D}$ and $\mathrm{B}$ particles in different fluidization regimes, The Canadian Journal of Chemical Engineering , 84 (2006) 656-663

[5] A. H. Zahed, J. X. Zhu, J. R. Grace, Modelling and Simulation of Batch and Continuous Fluidized Bed Dryers, Drying Technology, 13 (1995) 1-28

[6] B. Ramakers, Fluidization Behavior of Wood/Sand Mixtures, 14th International Drying Symposium, Sao Paulo, Brazil, 2004
[7] F. Scala, Mass Transfer around Freely Moving Active Particles in the Dense Phase of a Gas Fluidized Bed of Inert Particles, Chemical Engineering Science, 62 (2007), $16,4159-4176$

[8] M. Djaeni, Energy Efficient Multistage Zeolite Drying for Heat Sensitive Products, Ph. D. thesis, Wageningen University, Wageningen, The Netherlands, 2008

[9] D. Geldart, Types of gas fluidization, Powder Technology, 7, (1973) 285-292

[10] H. Kage, M.Tsumori, A. Sasaki, Y. Matsuno, Application of the obstruction model to elutriation of more than one species of particles from multicomponent fluidized bed, Journal of Chemical Engineering of Japan, 25 (6) (1992) 672-677

[11] P. N. Rowe, Prediction of bubble size in a gas fluidized bed, Chemical Engineering Science, 31 (4) (1976) 285-288

[12] S. Chiba, T. Chiba, W. Nienow, H. Kobayashi, The Minimum Fluidization Velocity, Bed Expansion and Pressure-Drop Profile of Binary Particle Mixtures, Powder Technology, 22 (1979) 255-269

[13] D. Kunii, O. O. Levenspiel, Fluidization Engineering, Ed. Butterworth - Heinemann E. U. A., 1-82 (1991) 105-106

[14] S. Y. Wu, J. Baeyens, Segregation by size difference in gas fluidized beds, Powder Technology, 98 (1998) 139-150

[15] A. Sahoo, G. K. Roy, Mixing characteristic of homogeneous binary mixture of regular particles in gas - solid fluidized bed, Powder Technology, 159 (2005) 150-154

[16] S. L. Jariwara, H. E. Hoelscher, Ind. Eng. Chem. 9 (2) (1970) 278-284

[17] W. J. Chancellor, Trans. ASAE 11 (1968) 857-867

[18] D. H. Lee, S. D. Kim, Drying Characteristics of Starch in an Inert Medium Fluidized Bed, Chemical Engineering Technology, 16 (1993) 263-269

[19] J. Janevski, Drying of grained material in two-component fluidized bed, PhD Thesis, Faculty of Mechanical Engineering, University of Nis, 2009 


\section{EKSPERIMENTALNO ISTRAŽIVANJE UTICAJA TEMPERATURE VAZDUHA I MASENOG ODNOSA ZEOLITA I INERTNOG MATERIJALA NA EFIKASNOST PROCESA SUŠENJA U FLUIDIZOVANOM SLOJU}

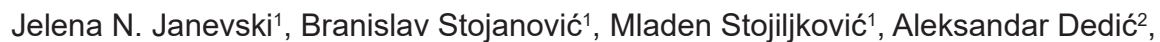
Predrag Živković ${ }^{1}$
(ORIGINALNI NAUČNI RAD) UDK 66.096.5:549.67

${ }^{1}$ Mašinski fakultet, Univerzitet u Nišu, Niš, Srbija

2Šumarski fakultet, Univerzitet u Beogradu, Beograd, Srbija

Fluidizacija je poslednjih decenija postala predmet velikog interesovanja u oblasti procesne industrije i hemijskog inženjerstva. Ovaj rad prikazuje deo rezultata istraživanja kinetike sušenja sitnozrnastog materijala u dvokomponentnom fluidizovanom sloju. Dat je kratak pregled teorijskog i eksperimentalnog istraživanja aerodinamike fluidizovanog sloja i minimalne brzine fluidizacije sa posebnim osvrtom na dvokomponentne fluidizovene slojeve (binarne mešavine), kao i osnove toplotnog i materijalnog bilansa u sloju. Uzajamna spregnutost hidrodinamike i prenosnih mehanizama komplikuje analizu, dizajn i predviđanja procesa kod gasom fluidizovanih slojeva. Bazirajući se na eksperimentalnim istraživanjima u kojima je zeolit korišćen kao fini sitnozrnasti materijal a poletilen kao inertni materijal (druga komponenta), prikazana je analiza uticaja radnih parametara na proces sušenja u dvokomponentnom fluidizovanom sloju. Pre toga, eksperimentalno su određivane minimalne brzine u dvokomponentnom fluidizovanom sloju sa cesticama različitih veličina i gustina. Takođe je ukratko opisana sposobnost odnošenja finih čestica iz sloja. $U$ radu su krivama sušenja prikazani rezultati eksperimentalnog istraživanja uticaja određenih parametara kao što su temperatura agensa sušenja i odnos masenog učešća zeolita i inertnog materijala. Učešće inertnog materijala može znatno povećati intenzitet prenosa toplote i materije u fluidizovanom sloju.
Ključne reči: fluidizacija, sloj, eksperiment, čestice, zeolit, sušenje 